\title{
Organic Rankine Cycle Based Geothermal Energy for Power Generation in Egypt
}

\author{
Doaa M. Atia, Hanaa M. Farghally, Ninet M. Ahmed, Hanaa T. El-Madany \\ Photovoltaic Cells, Electronics Research Institute, Cairo, Egypt \\ Email: doaa @eri.sci.eg
}

How to cite this paper: Atia, D.M., Farghally, H.M., Ahmed, N.M. and El-Madany, H.T. (2017) Organic Rankine Cycle Based Geothermal Energy for Power Generation in Egypt. Energy and Power Engineering, 9, 814-828.

https://doi.org/10.4236/epe.2017.912051

Received: October 10, 2017

Accepted: November 22, 2017

Published: November 27, 2017

Copyright $\odot 2017$ by authors and Scientific Research Publishing Inc. This work is licensed under the Creative Commons Attribution International License (CC BY 4.0).

http://creativecommons.org/licenses/by/4.0/

\begin{abstract}
Low temperature geothermal resources are located in many areas and represent a high potential energy resource. One of the most common technologies, efficient and to exploit this type of resource is the binary cycle technology. Organic Rankine Cycle (ORC) is one of the main types of binary cycles. Electricity generation from low enthalpy geothermal energy using ORC is a talented technology. This paper addresses the design of binary cycle power plant utilizing one of the low temperature geothermal resource of temperature $92^{\circ} \mathrm{C}$ using four alternative working fluids: Butane, Isobutane, Pentane and 1,1,1,3,3-Pentafluoropropan (R245fa). Bir Nabi is the well under consideration which located in the Eastern desert, Egypt. Three operation parameters: geothermal temperature, reinjection temperature and geothermal flow rate are taken into consideration to analyze the performance of the power plant for different fluids. A performance analysis is conducted on ORC binary power plant using MATLAB programming to study the variation of output power and efficiency with the operation parameters. Also, the effect of these parameters on the area of ORC binary cycle power plant components; preheater, evaporator and condenser is presented. The geothermal resources temperatures are in the range of $90^{\circ} \mathrm{C}$ to $130^{\circ} \mathrm{C}$, the mass flow rate of the geothermal fluid ranges between $10 \mathrm{~kg} / \mathrm{s}$ and $50 \mathrm{~kg} / \mathrm{s}$ and reinjection temperature ranges from $30^{\circ} \mathrm{C}$ to $70^{\circ} \mathrm{C}$. The results indicate that, the highest output power and plant efficiency are obtained with Pentane.
\end{abstract}

\section{Keywords}

Geothermal Energy, Working Fluid, Organic Rankine Cycle Binary Power Plant

\section{Introduction}

Renewable energy demand is increasing according to the shortage of non-renewable 
energy resources and their environmental problems. Therefore, electricity generation from the renewable energy sources has a vital importance since it serves as an optimal solution for energy and environmental issues. The biomass, solar, wind, geothermal and oceanic energy are used to tackle the energy crisis. The geothermal energy is a clean, continuous sustainable energy resource and the amount of energy [1] [2]. The low to medium temperature sources are used for thermal heating not in electrical energy generation. In order to generate electricity from low to medium geothermal temperature sources and to increase the utilization of thermal resources by recovering waste heat, binary technologies have been developed [3]. Over the world, the installed capacity of geothermal energy is divided into $48,493 \mathrm{MWt}$ thermal and 117,740 GWh electrical in different 78 countries; the top countries are China, USA, Sweden, Turkey and Japan. Currently, the geothermal binary power plants installed is about $800 \mathrm{MWe}$, representing $8 \%$ of the total geothermal power. The binary power plants are widely used types of geothermal power plant with 193 units in 17 countries [4]. Nowadays, the most common technology for utilizing low temperature geothermal sources for electricity generation is binary cycle power plants. Binary plants are usually constructed in small integrated units of a few hundred kWe to a few MWe capacities [5]. Generally, there are two main types of a binary cycle which are the Organic Rankine Cycle (ORC) and the Kalina cycle. The ORC commonly uses hydrocarbons as the appropriate working fluid and Kalina uses water ammonia mixture [6] [7]. The ORC plant is more economical for geothermal fluid temperature below $180^{\circ} \mathrm{C}$ [3]. The main purpose of this work is to generate a power from low temperature geothermal resources using an ORC plant and compare the output power and efficiency for different working fluids. Also, sensitivity analysis of the output generated power to the variation of geothermal temperature, reinjection temperature and geothermal flow rate is performed.

\section{Geothermal Energy in Egypt}

Nowadays, it is required to increase the use of renewable energy in Egypt up to $20 \%$ by 2020 . Wind and solar energy are used recently. Geothermal energy till now not used for electricity production, the direct used is recently utilized. North eastern corner of African continent may possess geothermal resources. The Gulf of Suez is characterized with hot spring with different temperature. So, it is the most promising area of geothermal in Egypt. A number of geo-thermometric studies are enhanced for the geothermal water in Egypt. the previous research articles pointed out that Hammam Faraun area attains the highest recorded subsurface formation temperature $\left(94.86^{\circ} \mathrm{C}\right)$ and heat flow $\left(121.67 \mathrm{~mW} / \mathrm{m}^{2}\right)$ values among the other studied areas; the values that are in harmony with the average temperature $\left(95^{\circ} \mathrm{C}\right)$ and heat flow $\left(116 \mathrm{~mW} / \mathrm{m}^{2}\right)$ values obtained from the analysis of temperature data [8] [9]. The most common direct use are; district heating, aquaculture, agricultural applications, and swim- 
ming pools are already constructed along the eastern coastal parts of Gulf of Suez.

The geothermal resources of Egypt can be classified as three main types; low enthalpy geothermal resources which are located mainly in the Western desert of Egypt, around the Gulf of Suez and in some locations in Sinai. The second type is medium enthalpy geothermal resources represented by some hot springs and geothermal targets around Gulf of Suez. The third type is high enthalpy geothermal resources where geothermal anomalies encountered in the rift of depo-centres areas of the Gulf of Suez and Red Sea [8] [9] [10] [11].

\section{Binary Cycle Power Plant Configuration}

To design a binary power plant, it is required to design its components which are preheater, evaporator, condenser, feed pump, turbine, generator and cooling tower. Figure 1 illustrates the desired binary cycle power plant scheme. The function of preheater is to provide a sufficient heat to raise the organic fluid to its boiling point. The evaporator is used for evaporating the boiled working fluid [12] [13]. The pressurized vapour steam of organic fluid expands in the turbine and leads to rotation of the rotor. The rotational kinetic energy is converted to electricity using the rotor connected to a generator. The thermal energy from the organic fluid is converted to electrical energy through the generator. The condenser condenses the working fluid vapor steam out from turbine due to the transfer of its heat to the cooling water for changing its phase to a liquid state before entering the feed pump [14] [15].

\section{Selection of Working Fluid}

For binary power cycles design, the main challenges of the ORC are the choice of an appropriate working fluid. A common characteristic of all working fluids used in binary cycle power plant is their low boiling point [16] [17]. They also have critical temperatures and pressures lower than water. In order to give a representative review of the organic working fluids that can be used in a geothermal binary power plant, three hydrocarbons (Butane, Isobutane and Pentane) and one synthetic refrigerant (R245fa) are tested. The thermodynamic properties such as critical temperature, critical pressure, etc., of the working fluid strongly influence the performance of the system. These properties are not the only criteria to be taken into account during the selection of a working fluid; other key criteria include the impact of the working fluid on total system cost, health safety and environmental impacts [18] [19]. The thermodynamic, environmental and health properties of some of the working fluids considered best for low temperature reservoir binary plants are shown in Table 1 [2].

\section{Thermodynamic Modeling}

The design of a geothermal binary plant needs to take into account the particular type of thermodynamic cycle, pump, turbine, heat exchanger, condenser, and 


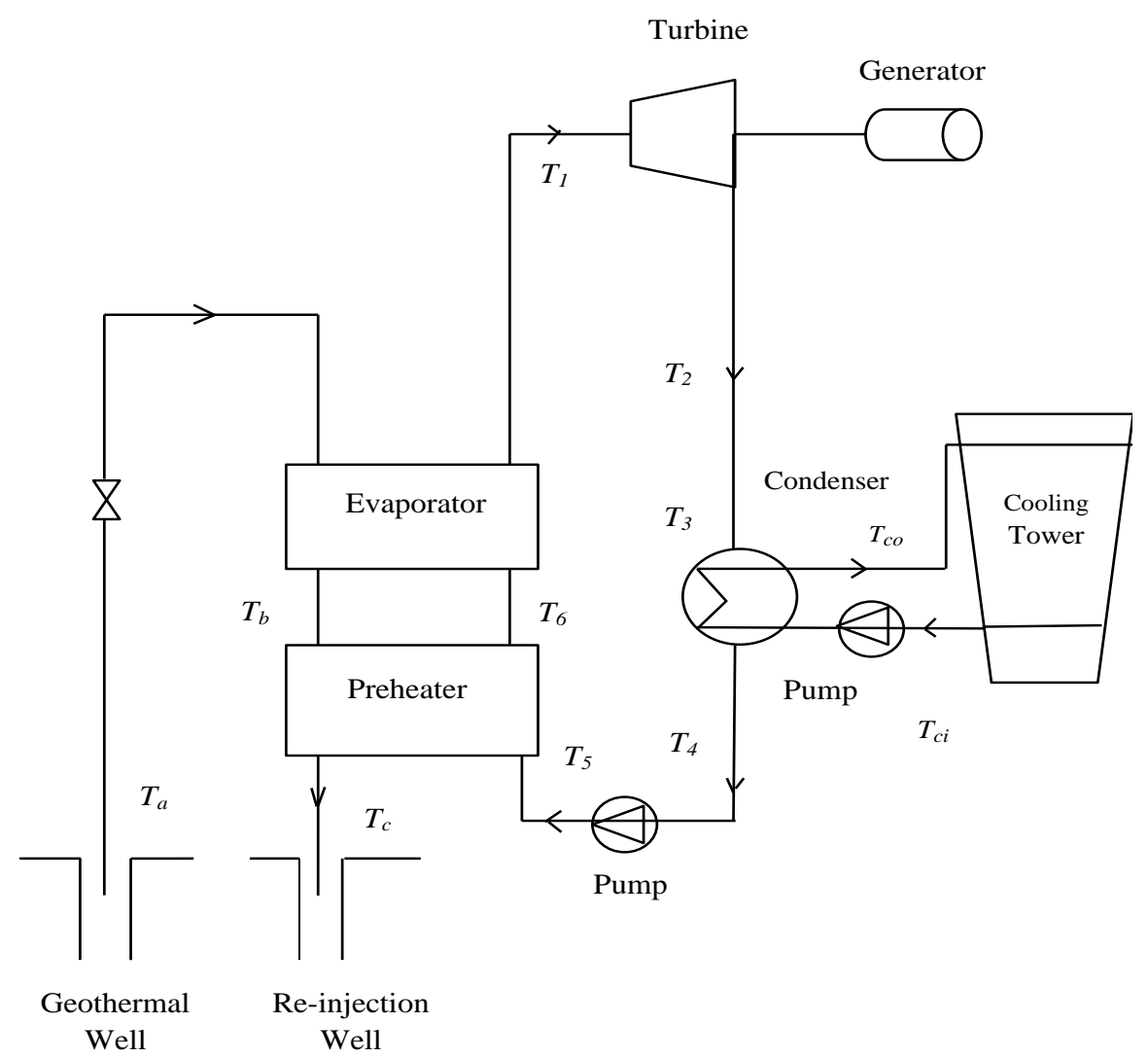

Figure 1. Configuration of geothermal binary cycle power plant.

Table 1. Thermodynamics health and environmental properties of some candidate working fluids.

\begin{tabular}{cccccccccc}
\hline Fluid & Formula & $\begin{array}{c}\text { Critical } \\
\text { temp. } \\
\left({ }^{\circ} \mathrm{C}\right)\end{array}$ & $\begin{array}{c}\text { Critical } \\
\text { pressure } \\
(\mathrm{bar})\end{array}$ & $\begin{array}{c}\text { Molar } \\
\text { mass } \\
(\mathrm{kg} / \mathrm{kmol})\end{array}$ & Toxicity & Flammability & ODP $^{1}$ & GWP $^{2}$ \\
\hline Butane & C4H10 & 150.8 & 37.18 & 58.12 & Low & Very high & 0 & 3 \\
Isobutane & i-C4H10 & 135.9 & 36.85 & 58.12 & Low & Very high & 0 & 3 \\
Pentane & C5H12 & 193.9 & 32.40 & 72.15 & Low & Very high & 0 & 3 \\
R245fa & C3H3F5 & 154.0 & 36.51 & 134.0 & Low & Non-flam & 0 & 1030 \\
\hline
\end{tabular}

1: ozone depletion potential; 2: global warming potential.

cooling system. The energy analysis based on the first and second laws of thermodynamics is evaluated for different organic working fluids under diverse working conditions. A thermodynamic model of the conceptual design is developed using MATLAB program. The thermodynamic heat balance is given as [20]:

$$
\begin{gathered}
h_{2}=h_{1}-\eta_{t u r}\left(h_{1}-h_{2 s}\right) \\
h_{5}=h_{4}+\left(h_{5 s}-h_{4}\right) / \eta_{p}
\end{gathered}
$$

where, $h_{2}$ is the turbine input enthalpy, $h_{1}$ is enthalpy of the working fluid, $\eta_{t u r}$ is the turbine efficiency, $h_{2 s}$ is isentropic enthalpy of the working fluid after the 
turbine, $h_{4}$ is the condenser outlet enthalpy, $h_{5}$ is the enthalpy of organic fluid entering the evaporator $(\mathrm{kJ} / \mathrm{kg}), h_{5 s}$ is the enthalpy of the working fluid assuming isentropic process, $\eta_{p}$ is the pump efficiency. The outlet temperature of the cooling water is calculated from the inlet cooling temperature, which is increased by raising the temperature of the cooling water in the condenser as [20]:

$$
T_{c o}=T_{c i}+T_{\text {delta }}
$$

where $T_{c o}$ is the outlet cooling temperature, $T_{c i}$ is the inlet cooling temperature and $T_{\text {delta }}$ is the increase of inlet water temperature in the condenser caused by heat transfer between the cooling water and the working fluid. Evaporator mass balance equation and Preheater mass balance equation are given by [21] [22]:

$$
\begin{gathered}
m_{b} C_{p b}\left(T_{a}-T_{b}\right)=m_{w f}\left(h_{1}-h_{6}\right) \\
m_{b} C_{p}\left(T_{b}-T_{r}\right)=m_{w f}\left(h_{6}-h_{5}\right)
\end{gathered}
$$

where $m_{b}$ is the brine mass flow rate $(\mathrm{kg} / \mathrm{s}), C_{p b}$ is the specific heat of brine $(\mathrm{kJ} / \mathrm{kg} \mathrm{K})$, and $m_{w f}$ is the working fluid flow rate, $T_{b}$ is the brine temperature, $T_{r}$ is the reinjection temperature. $h_{5}$ and $h_{6}$ are the enthalpy of preheater and evaporator respectively. The relationship between the mass flow of the working fluid and the mass flow of the cooling water is given by mass balance equations. Cooling water mass flow is given by [21]:

$$
m_{c w} C_{p w}\left(T_{c o}-T_{c i}\right)=m_{w f}\left(h_{2}-h_{4}\right)
$$

where $m_{c w}$ is the cold water flow rate $(\mathrm{kg} / \mathrm{s}), C_{p w}$ is the specific heat of cold water $(\mathrm{kJ} / \mathrm{kg} \mathrm{K})$. The condenser is used to condensate the steam leaving the turbine. It exchanges the heat between the cooling fluid cycle and the working fluid vapour. Condensing temperature determination [21]:

$$
m_{c w} C_{p w}\left(T_{\text {cond }}-T_{c i}\right)=m_{w f}\left(h_{4}-h_{5}\right)
$$

where and $T_{\text {cond }}$ is the temperature of condensation (K). Heat rejected from the working fluid to the cooling water in the condenser $\left(Q_{c}\right)$ is calculated using enthalpies of inlet and outlet parameters of the working fluid in the condenser [2]:

$$
Q_{c}=m_{w f}\left(h_{2}-h_{4}\right)
$$

The output power of the plant can be calculated using the following equations [2]:

$$
\begin{gathered}
w_{n e t}=w_{t}-w_{p}-w_{f} \\
w_{t}=m_{w f}\left(h_{1}-h_{2}\right) \\
w_{p}=m_{w f}\left(h_{5}-h_{4}\right) \\
w_{f}=p_{f} \eta_{f}
\end{gathered}
$$

The power used by the fan to move air through the cooling system $\left(Q_{t}\right)$ is given by:

$$
Q_{t}=m_{g} C_{p}\left(T_{a}-T_{r}\right)
$$


Electric power produced in the turbine, which is lowered by parasitic losses, is called net power. Net power is the total electric power produced by the power plant which can be sent to a network for use. Where $W_{\text {net }}$ is the net power output of power plant, $W_{t}$ is the power produced by turbine, $W_{p}$ is the power used by all pumps in cycle and $W_{f}$ is the power used by cooling fans, $p_{f}$ is fan power, $\eta_{f}$ is the efficiency of the fan motor, $\dot{m}_{g}$ is geothermal flow rate. The system efficiency $\left(\eta_{\text {net }}\right)$ for an ORC system is defined as [19]:

$$
\eta_{\text {net }}=\frac{w_{\text {net }}}{Q_{t}}
$$

The required area for the plant component can be calculated after the heat transfer for different component. Preheater area can be calculated according to [2]:

$$
\begin{gathered}
A=\frac{Q}{U L M T D} \\
L M T D=\frac{\left(\left(T_{b-} T_{5}\right)-\left(T_{r}-T_{4}\right)\right)}{\left(\log \left(\left(T_{b}-T_{5}\right)\right) /\left(T_{r}-T_{4}\right)\right)}
\end{gathered}
$$

where $T_{b}$ is the temperature of geothermal leaving the evaporator. Evaporator area can be calculated according to [2]:

$$
\text { LMTD }=\frac{\left(\left(T_{a-} T_{1}\right)-\left(T_{b}-T_{5}\right)\right)}{\left(\log \left(\left(T_{a}-T_{1}\right)\right) /\left(T_{b}-T_{5}\right)\right)}
$$

Condenser area can be calculated according to [2]:

$$
L M T D=\frac{\left(T_{2-} T_{c o}\right)-\left(T_{\text {cond }}-T_{a}\right)}{\left(\log \left(T_{2}-T_{c o}\right) /\left(T_{\text {cond }}-T_{a}\right)\right)}
$$

where $U$ is the overall heat transfer coefficient $\left({ }^{\circ} \mathrm{C} / \mathrm{m}^{2}\right), A$ is the heat transfer area $\left(\mathrm{m}^{2}\right)$, and $L M T D$ is the Logarithmic Mean Temperature Difference $\left({ }^{\circ} \mathrm{C}\right)$.

\section{Results and Discussion}

Bir Nabi in the Eastern desert, Egypt of temperature $92^{\circ} \mathrm{C}$ is used as the well under test [22]. A sensitivity analysis of the binary cycle output power is presented for the variation of geothermal temperature, geothermal flow rate and reinjection temperature for the four alternative working fluids; Butane, Isobutane, Pentane and R245fa. These results are obtained on the basis of a constant ambient and condensation temperatures of $26^{\circ} \mathrm{C}$ and $30^{\circ} \mathrm{C}$, respectively. To make the comparison meaningful, some parameters for heat source sink and power plant components have been selected as fixed values. Table 2 gives the initial condition and the assumptions for the plant design.

Table 3 shows the output power and efficiency for the selected four working fluids calculated at geothermal temperature of $92^{\circ} \mathrm{C}$, reinjection temperature of $70^{\circ} \mathrm{C}$ and geothermal flow rate of $20 \mathrm{~kg} / \mathrm{s}$. It was found from Table 3 that, Pen- 
Table 2. Assumptions for heat source sink and power plant component.

\begin{tabular}{lc}
\hline The temperature of the geothermal water & $92^{\circ} \mathrm{C}$ \\
The temperature of the cooling water & $20^{\circ} \mathrm{C}$ \\
The pinch temperature difference in both heat exchangers & $5{ }^{\circ} \mathrm{C}$ \\
Isentropic efficiencies for the turbine & $80 \%$ \\
Isentropic efficiencies for the pump & $75 \%$ \\
Generator efficiency & $96 \%$ \\
Water pump efficiency & $75 \%$ \\
Turbine outlet quality & 90
\end{tabular}

Table 3. ORC plant results.

\begin{tabular}{ccc}
\hline Working fluid material & Total power $(\mathrm{kW})$ & Effeciency (\%) \\
\hline Butane & 185 & 10 \\
Isobutane & 180.5 & 9.7 \\
Pentane & 213 & 11.5 \\
R245fa & 176 & 9.5 \\
\hline
\end{tabular}

tane meets our demand, giving the highest output power of approximately 213 $\mathrm{kW}$ and the highest thermal efficiency of $11.5 \%$. On the other hand, R245fa yielded the lowest power output and the lowest efficiency.

Figure 2 shows the variation of the net power output with geothermal temperature for the four working fluids at geothermal flow rate and reinjection temperature of $20 \mathrm{~kg} / \mathrm{s}$ and $70^{\circ} \mathrm{C}$ respectively. It is shown that, the output power of the cycle is directly proportional with the geothermal temperature. Output power is positively correlated with geothermal temperature as this temperature increases the plant output power increases for all fluids. Also the pentane produces the highest power while the R245fa produce the lowest output power and the output power of Butane, Isobutane and R245fa are closer to each other especially for low geothermal temperature.

Figure 3 shows the variation of power output over a reinjection temperature range of $30^{\circ} \mathrm{C}$ to $70^{\circ} \mathrm{C}$ for different working fluids. The analysis is carried out using geothermal temperature and geothermal flow rate of $90^{\circ} \mathrm{C}$ and $20 \mathrm{~kg} / \mathrm{s}$, respectively. The reinjection temperature varies from $30^{\circ} \mathrm{C}$ to $70^{\circ} \mathrm{C}$ at keeping the other condition of the plant constant. For the different geofluid, it is clear that, the relation between output power and $T_{r}$ is negative correlated.

Figure 4 illustrates the variation of power output with geothermal flow rate for the used working fluids over a geothermal flow rate of $10-50 \mathrm{~kg} / \mathrm{s}$ at geothermal temperature and reinjection temperature of $90^{\circ} \mathrm{C}$ and $70^{\circ} \mathrm{C}$, respectively. More mass flows into a plant results in a larger amount of heat that is available to be converted into work. The Pentane produces the highest power while the R245fa produces the lowest output power. The output power of Butane, 


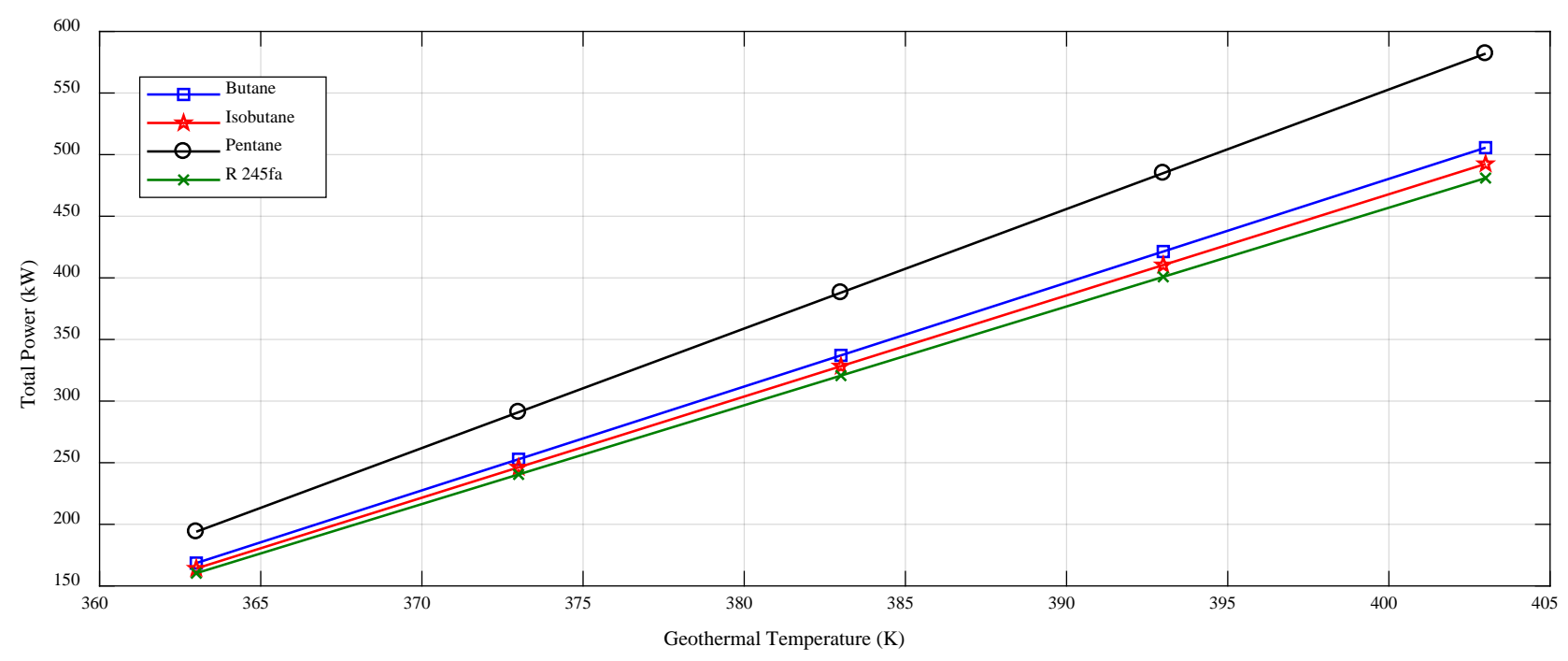

Figure 2. Variation of net power output with geothermal temperature for different working fluids.

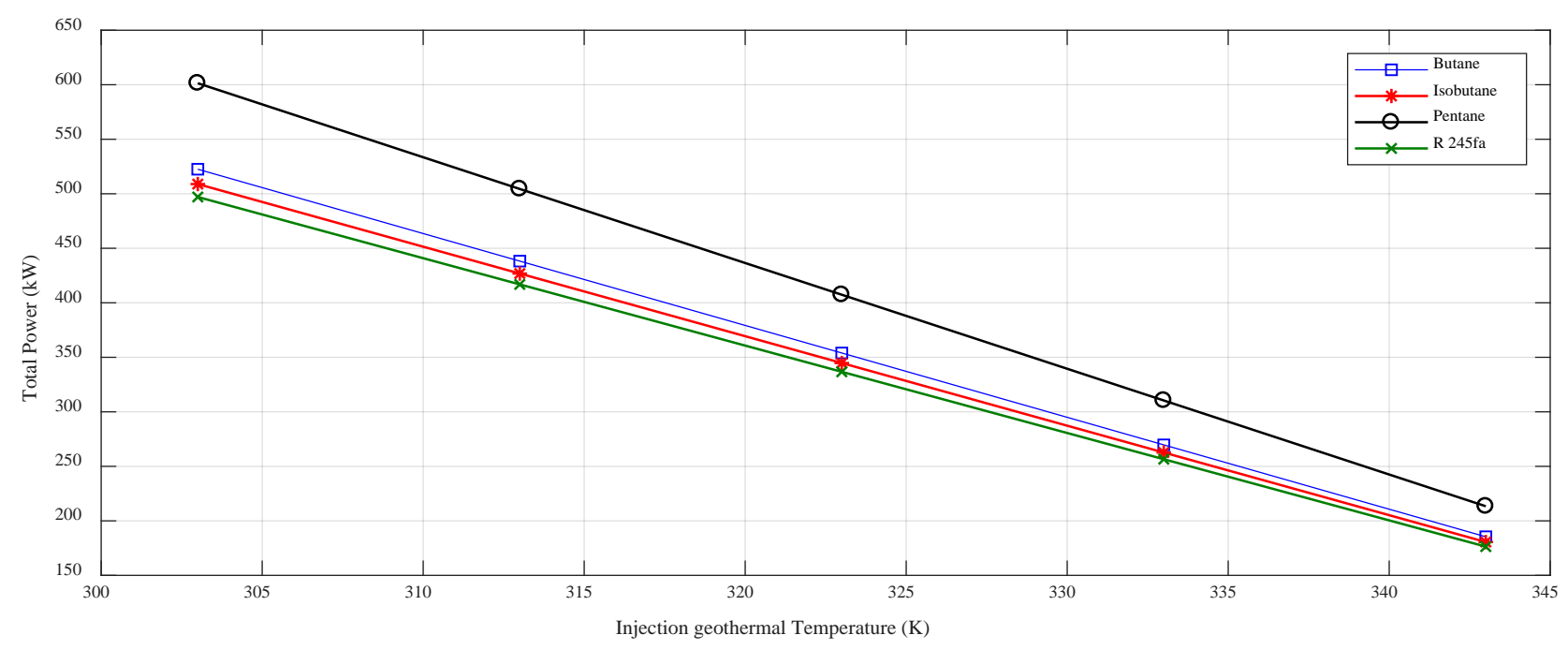

Figure 3. Variation of net power output with reinjection temperature for different working fluids.

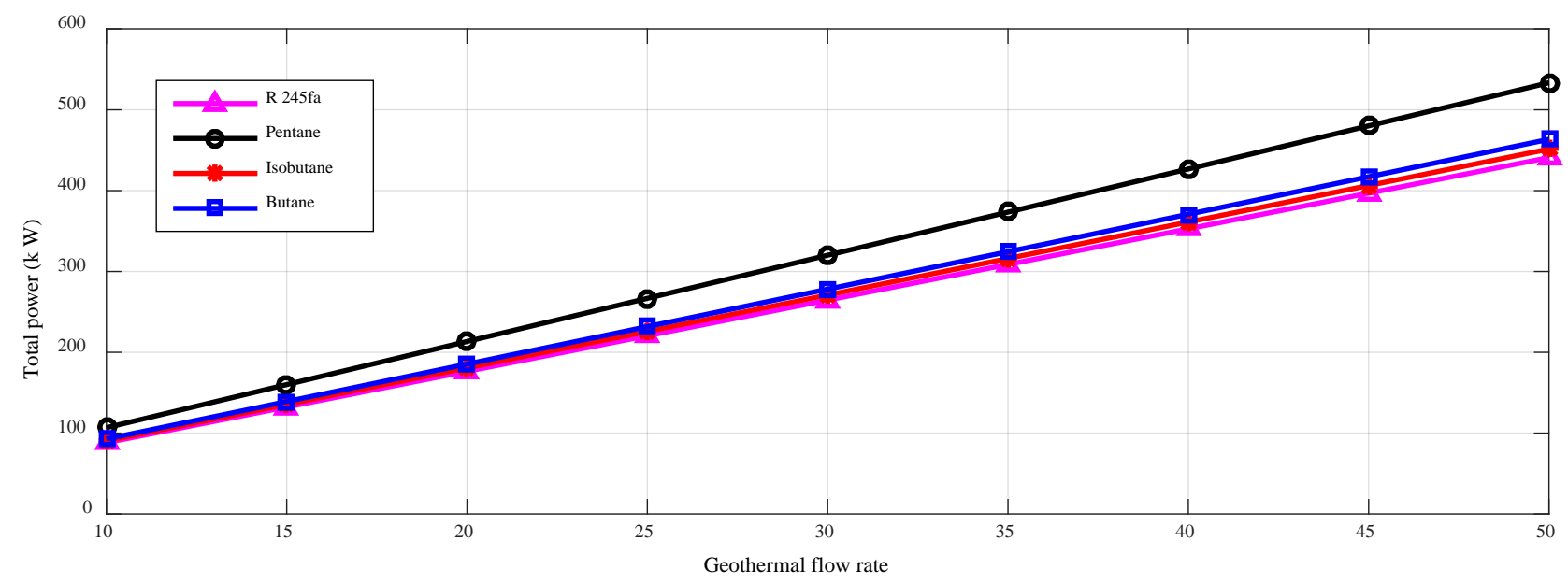

Figure 4. Variation of net power output with geothermal flow rate for different working fluids. 
Isobutan and R245fa are very closer to each other especially for low geothermal flow rate.

The variation of evaporator, preheater and condenser area with variation of geothermal temperature are given in Figure 5, Figure 6 and Figure 7. This reveals that, the heat exchanger area will be increased with the increase of the amount of heat transfer rate. The surface areas of these components exponentially increase with increasing geothermal temperature as seen in these figures. The heat exchangers designed area in case of Pentane is smaller than in case of R245fa working fluid. The difference of the heat transfer areas occurs because these cycle designs need different heat duty of the heat exchangers. Each heat exchanger design has a different overall heat transfer coefficient and logarithmic mean temperature difference (LMTD), which are the main factors affecting the heat exchanger. Each one of the working fluids has different thermodynamic properties; different areas of heat exchangers, evaporator and condenser are required.

The variation in the working fluid flow rate with geothermal fluid temperature is indicated in Figure 8. When the geothermal fluid temperature increases the working fluid flow rate is increased and larger quantity of working fluid passes through the fixed evaporator area. This causes an increase in the exit temperature of the working fluid from the evaporator and thus an increase in the level of working enthalpy parameter.

Figure 9 illustrates the variation of working fluid flow rate with the reinjection temperature. This flow rate is reduced with increasing reinjection temperature due to the reduction of amount of heat transfer rate with increasing reinjection temperature according to the energy balance equations.

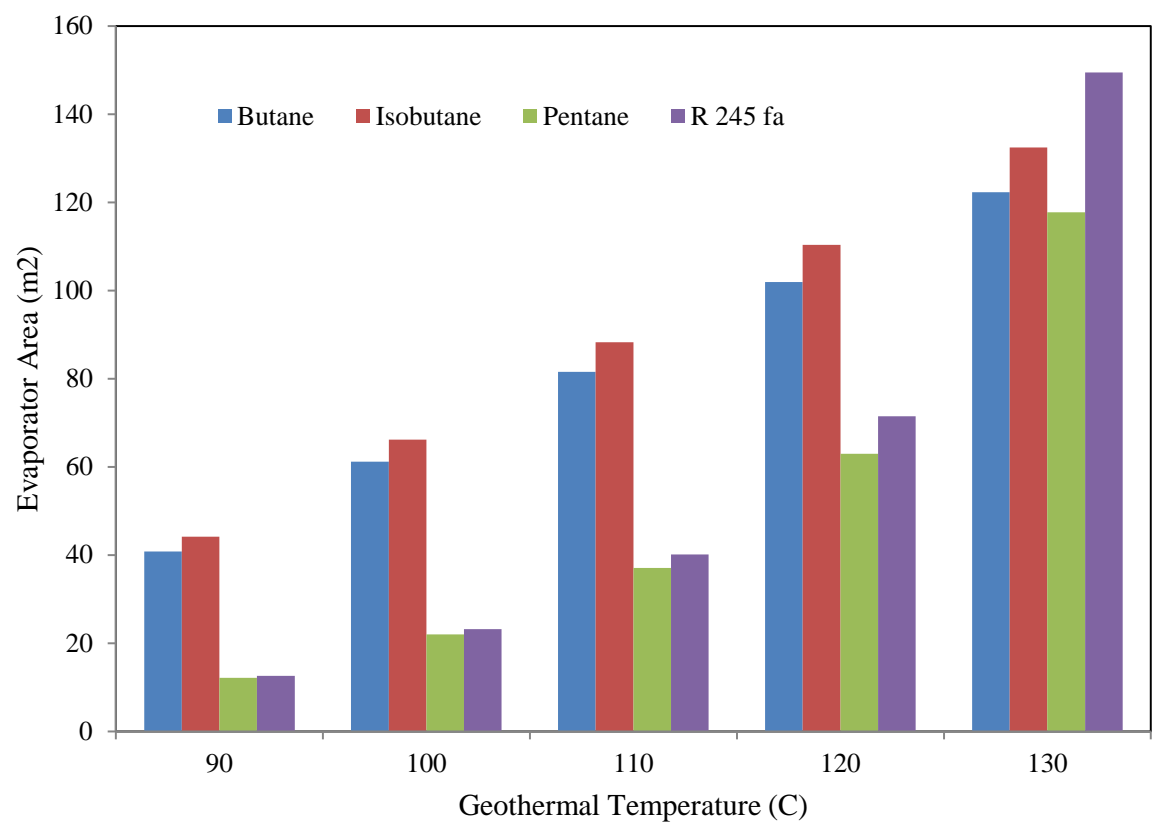

Figure 5. Evaporator area variations for different geothermal temperature. 


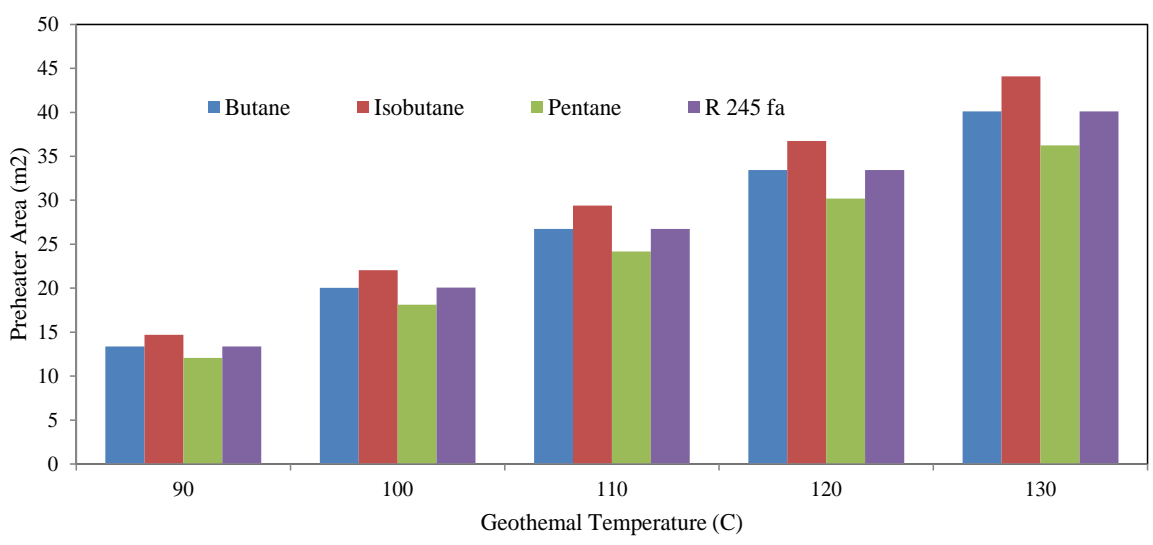

Figure 6. Preheater area variations for different geothermal temperature.

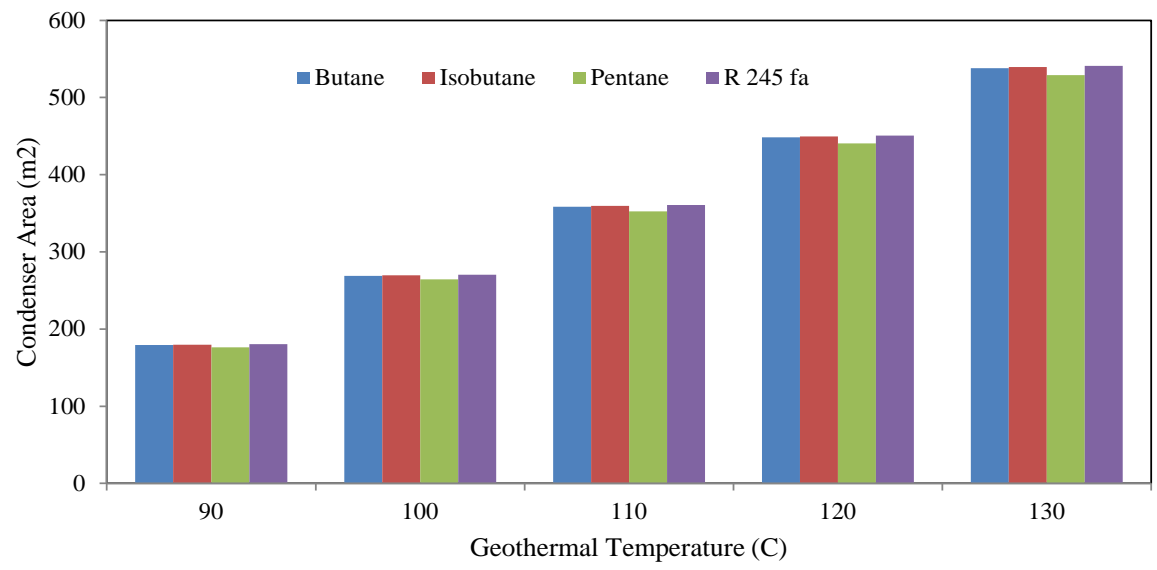

Figure 7. Condenser area variations for different geothermal temperature.

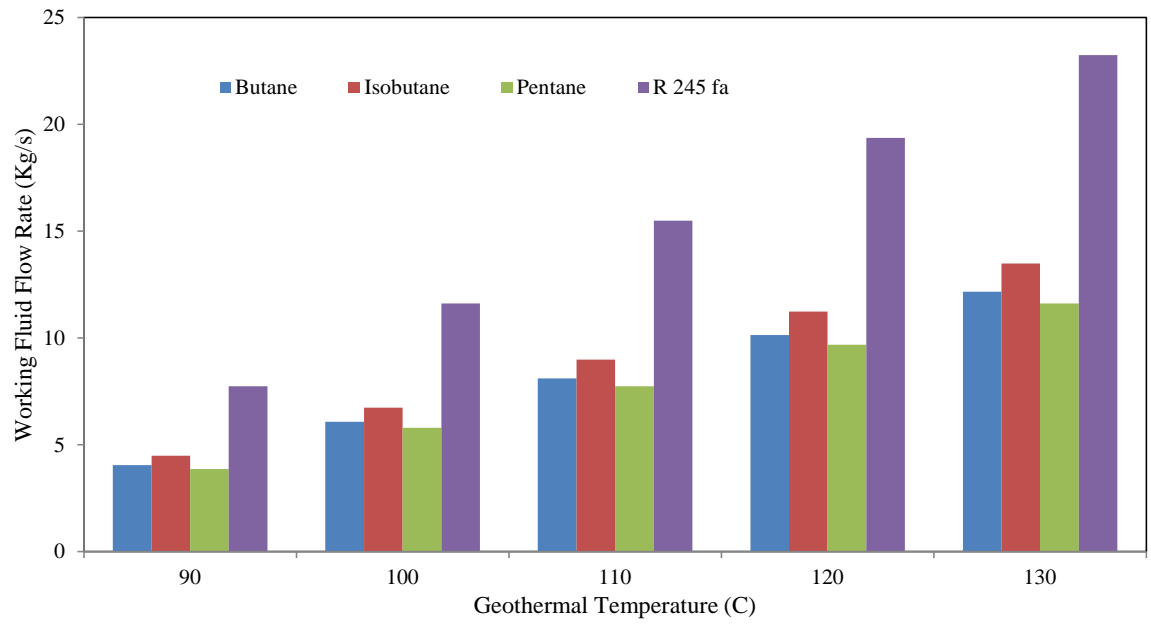

Figure 8. Working fluids flow rate variations for different geothermal temperature.

The calculated area of condenser and evaporator at different reinjection temperature for the four working fluids are shown in Figure 10 and Figure 11, respectively. These figures indicate that, as the reinjection temperature increases the area is reduced due to the reduction of the amount of heat transfer rate through evaporator and condenser. 


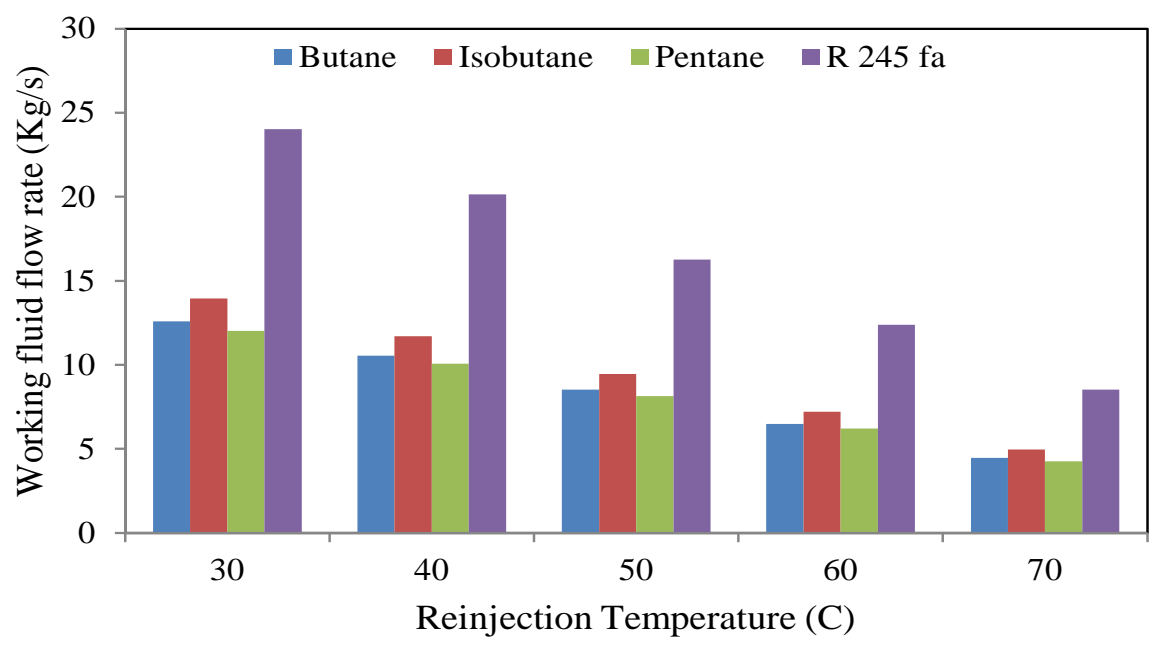

Figure 9. Working fluids flow rate variations for different reinjection temperature.

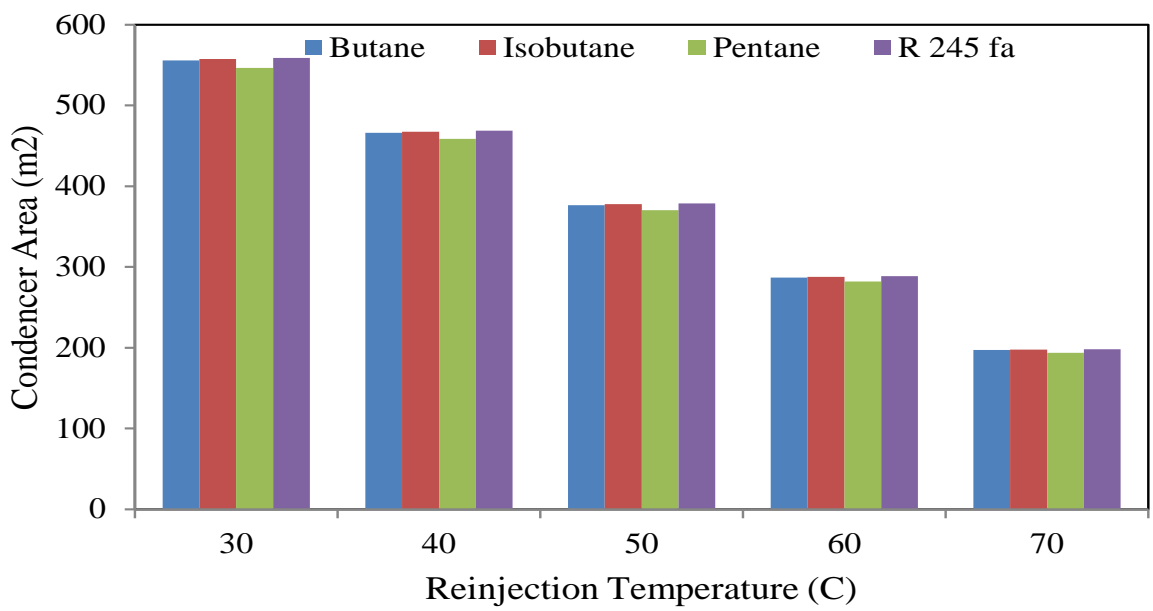

Figure 10. Condenser area variations for different reinjection temperature.

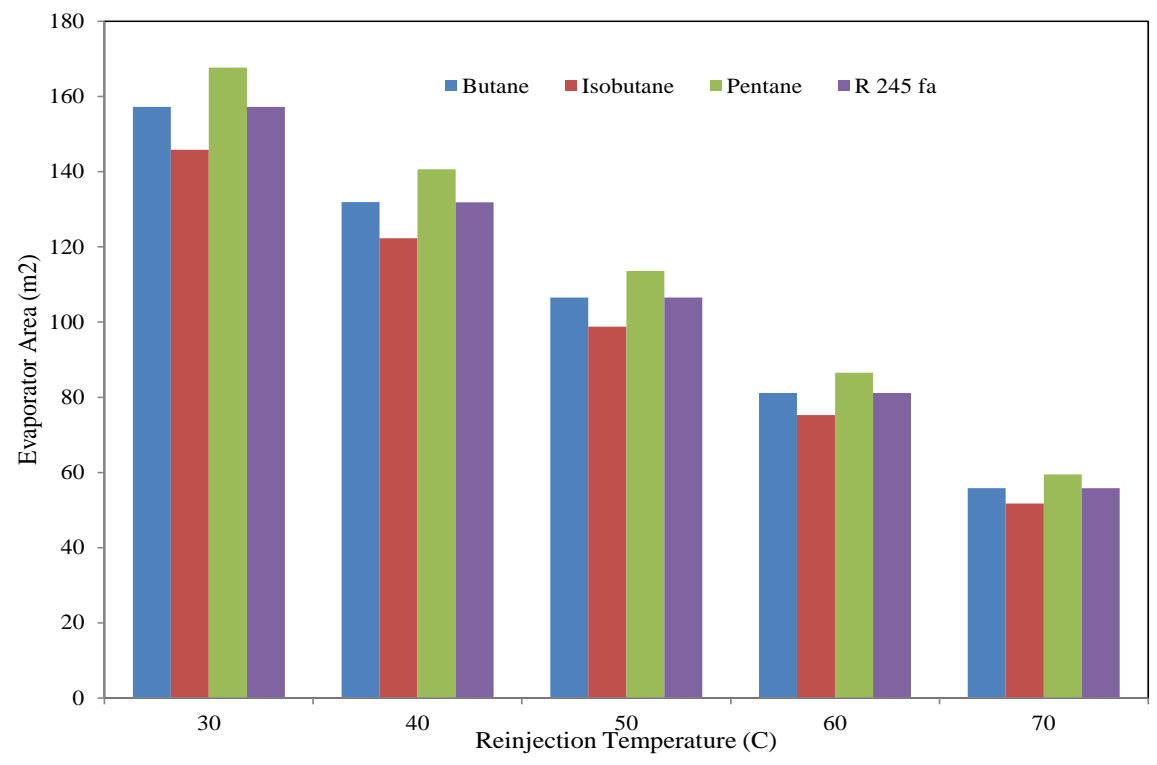

Figure 11. Evaporator area variations for different reinjection temperature. 


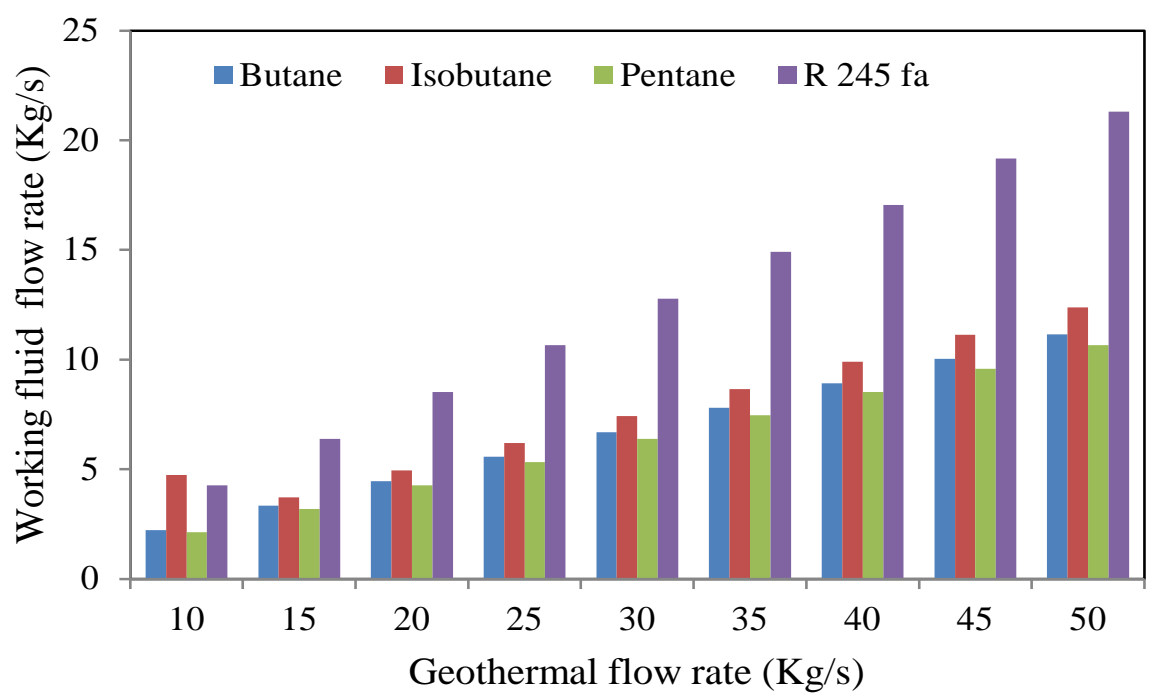

Figure 12. Working fluid flow rate variations for different geothermal flow rate.

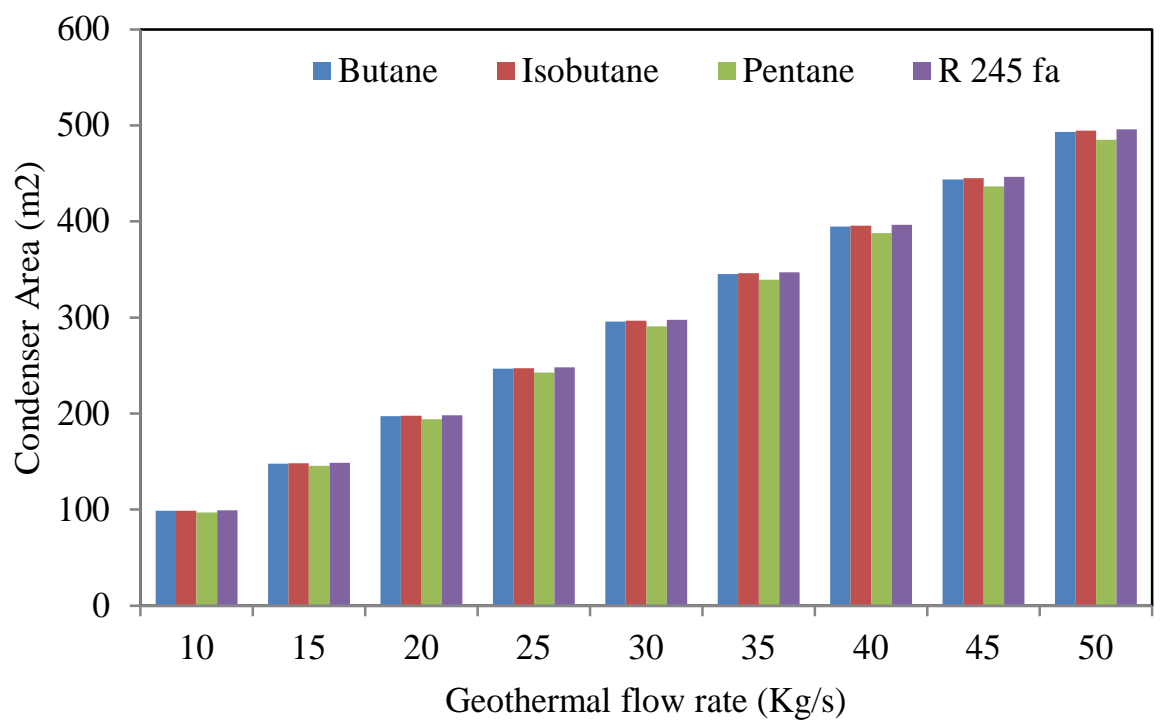

Figure 13. Condenser area variations for different geothermal flow rate.

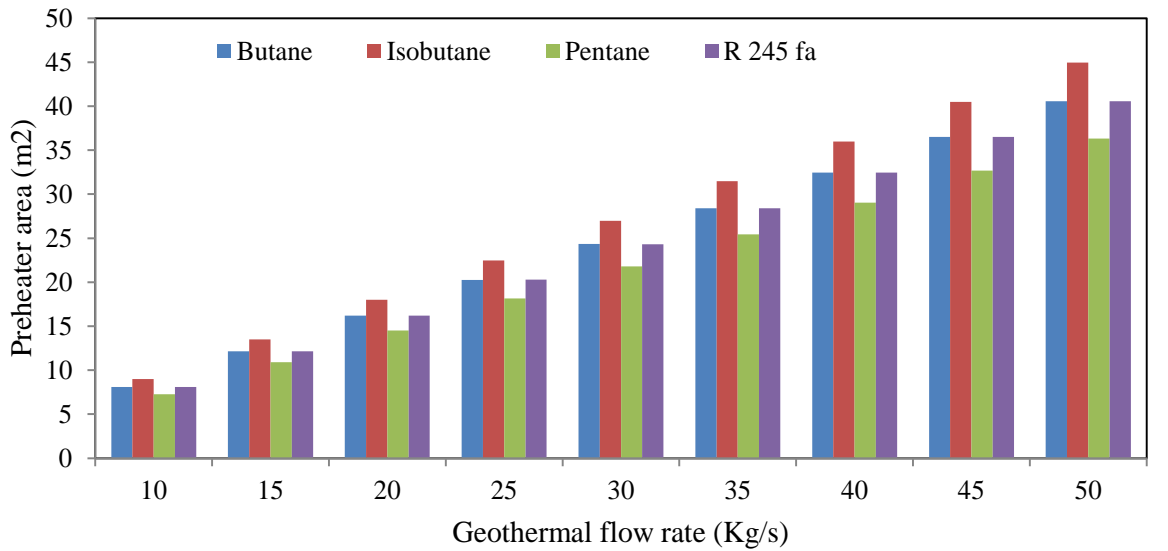

Figure 14. Preheater area variations for different geothermal flow rate. 


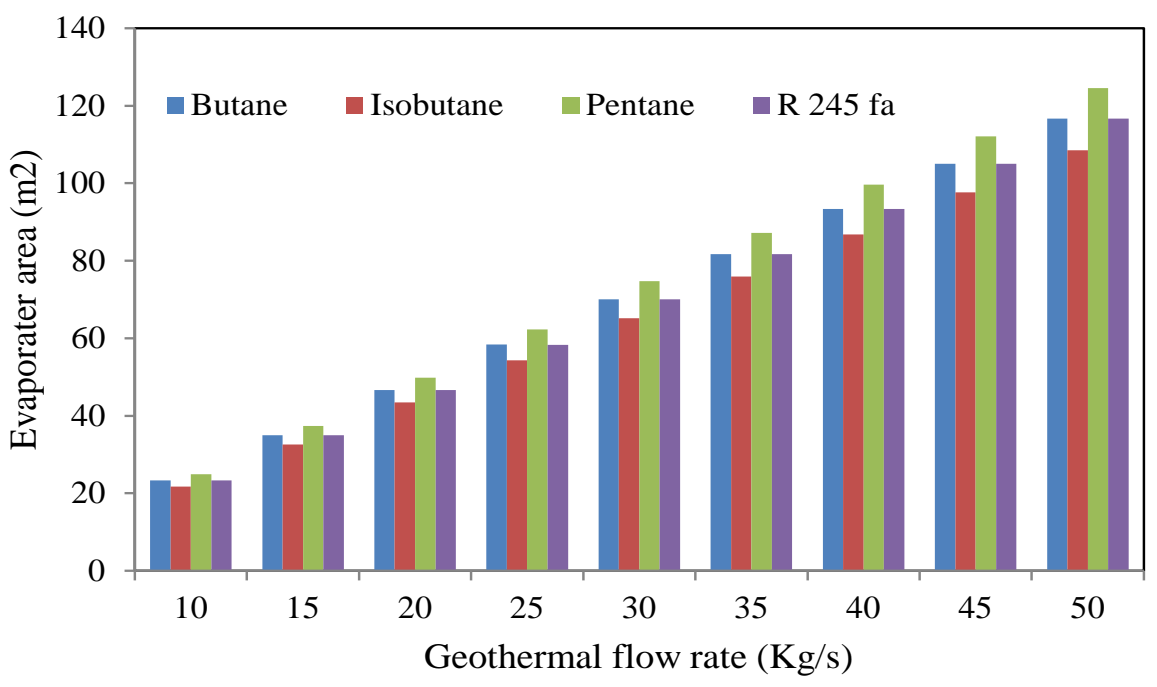

Figure 15. Evaporator area variations for different geothermal flow rate.

Figure 12 gives the variation of working fluid flow rate with geothermal flow rate variation. The variation of condenser, preheater and evaporator areas with the variation of geothermal flow rate are shown in Figure 13, Figure 14 and Figure 15, respectively. These figures reveal that, the area of these components increases with increasing the geothermal flow rates.

\section{Conclusion}

This paper proposed a design of ORC binary power plant for low temperature geothermal. The well under test is found in the Eastern desert of Egypt of temperature $92^{\circ} \mathrm{C}$. Four working fluids are used; one is a refergant R245fa and the others are hydrocarbons; Butane, Isobutane and Pentane. Among the four different fluids, Pentane has the best performance over the others. To evaluate the performance of ORC binary plant, a sensitivity analysis was done based on varying geothermal temperature, reinjection temperature and geothermal flow rate. These parameters were taking into consideration to study their effects on output power, net efficiency of the plant, and plant component design (preheater, evaporator and condenser area). Moreover, the effect of dependency of the flow rate of working fluid was studied on geothermal temperature and reinjection temperature. An increase in geothermal reservoir temperature and flow rate results in an increase of the total heat transfer rate and the produced output power and the efficiency of the plant. In contrast, an increase in reinjection temperature results in a decrease of the total heat transfer rate, the produced output power and the efficiency of the plant.

\section{References}

[1] Wang, H.X., Guo, T. and Zhang, S.J. (2011) Performance Comparison and Parametric Optimization of Subcritical Organic Rankine Cycle (ORC) and Transcritical Power Cycle System for Low-Temperature Geothermal Power Generation. Applied Energy, 88, 2740-2754. https://doi.org/10.1016/j.apenergy.2011.02.034 
[2] Kopuničová, M. (2009) Feasibility Study of Binary Geothermal Power Plants in Eastern Slovakia: Analysis of ORC and Kalina Power Plants. A Master's Thesis Done at RES the School for Renewable Energy Science. University of Iceland \& the University of Akureyripp, 1-69.

[3] Franco, A. (2011) Power Production from a Moderate Temperature Geothermal Resource with Regenerative Organic Rankine Cycles. Energy for Sustainable Development, 15, 411-419.

[4] http://www.renewableenergyworld.com/articles/print/volume-20/issue-1/features/g eothermal/2017-outlook-geothermal-is-trending-upwards.html

[5] Climate Technology Centre \& Network. Geothermal Systems and Technologies. 103-118.

[6] Matsuda, K. (2013) Low Heat Power Generation System. Chemical Engineering Transactions, 35, 223-228.

[7] Khennich, M. and Galanis, N. (2012) Optimal Design of ORC Systems with a Low-Temperature Heat Source. Entropy, 14, 370-389.

https://doi.org/10.3390/e14020370

[8] Lashin, A. (2015) Geothermal Resources of Egypt: Country Update. Proceedings World Geothermal Congress 2015, Melbourne, 1-13.

[9] El-Fiky, A.A. (2009) Hydrogeochemistry and Geothermometry of Thermal Groundwater from the Gulf of Suez Region, Egypt. Earth Sciences, 20, 71-96. https://doi.org/10.4197/Ear.20-2.5

[10] Kaiser, M.F. and Ahmed, S. (2013) Optimal Thermal Water Locations along the Gulf of Suez Coastal Zones, Egypt. Renewable Energy, 55, 374-379. https://doi.org/10.1016/j.renene.2012.12.033

[11] Zaher, M.A., Saibi, H., El Nouby, M., Ghamry, E. and Ehara, S. (2011) A Preliminary Regional Geothermal Assessment of the Gulf of Suez, Egypt. Journal of African Earth Sciences, 60, 117-132. https://doi.org/10.1016/j.jafrearsci.2011.02.006

[12] Liu, X.M., Wang, X. and Zhang, C.H. (2014) Sensitivity Analysis of System Parameters on the Performance of the Organic Rankine Cycle System for Binary-Cycle Geothermal Power Plants. Applied Thermal Engineering, 71, 175-183. https://doi.org/10.1016/j.applthermaleng.2014.06.048

[13] Parada, A.F.M. (2013) Geothermal Binary Cycle Power Plant Principles, Operation And Maintenance. Geothermal Training Programme Reports Orkustofnun. Grensasvegur 9, Number 20, IS-108 Reykjavik, 443-476.

[14] Budisulistyo, D. and Krumdieck, S. (2015) Thermodynamic and Economic Analysis for the Pre-Feasibility Study of a Binary Geothermal Power Plant. Energy Conversion and Management, 103, 639-649. https://doi.org/10.1016/j.enconman.2015.06.069

[15] Franco, A. (2012) Maurizio Vaccaro, Design Strategy of Geothermal Plants for Water Dominant Medium-Low Temperature Reservoirs based on Sustainability Issues. Proceedings of Ecos 2012 - The 25 th International Conference on Efficiency, Cost, Optimization, Simulation and Environmental Impact of Energy Systems, 26-29 June 2012, Perugia, 1-13.

[16] Madhawa Hettiarachchia, H.D., Golubovica, M., Woreka, W.M. and Ikegamib, Y. (2007) Optimum Design Criteria for an Organic Rankine Cycle using LowTemperature Geothermal Heat Sources. Energy, 32, 1698-1706. https://doi.org/10.1016/j.energy.2007.01.005

[17] Mikielewicz, D. and Mikielewicz, J. (2016) Criteria for Selection of Working Fluid 
in Low-Temperature Orc. Chemical and Process Engineering, 37, 429-440. https://doi.org/10.1515/cpe-2016-0035

[18] Bambang, T.P. and Suyanto, M.D.T. (2011) Model of Binary Cycle Power Plant using Brine as Thermal Energy Sources and Development Potential in Sibayak. International Journal of Electrical \& Computer Sciences, 11, 39-47.

[19] Coskun, A., Bolatturk, A. and Kanoglu, M. (2014) Thermodynamic and Economic Analysis and Optimization of Power Cycles for a Medium Temperature Geothermal Resource. Energy Conversion and Management, 78, 39-49. https://doi.org/10.1016/j.enconman.2013.10.045

[20] Wakana, F. (2013) Preliminary Study of Binary Power Plant Feasibility Comparing ORC and Kalina for Low-Temperature Resources in Rusizi Valley, Burundi. Geothermal Training Programme Reports 2013 Orkustofnun, Grensasvegur 9, Number 36, Is-108 Reykjavik, Icelan, 901-932.

[21] Franco, A. and Villani, M. (2009) Optimal Design of Binary Cycle Power Plants for Water-Dominated, Medium-Temperature Geothermal Fields. Geothermics, 38, 379-391. https://doi.org/10.1016/j.geothermics.2009.08.001

[22] Swanberg, C.A., Morgan, P. and Boulos, F.K. (1983) Geothermal Potential of Egypt. Tectonophysics, 96, 77-94. 